Pamiętnik Literacki 2020, 2, s. 39-51

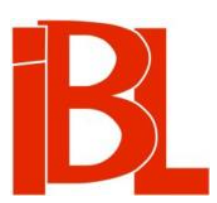

Specimen pudoris, czyli o rozmowie Jakuba Pizona z Lukrecją w epigramatach Andrzeja Krzyckiego

Witold Wojtowicz 
Pamiętnik Literacki CXI, 2020, z. 2, PL ISSN 0031-0514

DOI: $10.18318 / \mathrm{pl} .2020 .2 .3$

WITOLD WOJTOWICZ Instytut Badań Literackich PAN, Warszawa

\section{SPECIMEN PUDORIS, CZYLI O ROZMOWIE JAKUBA PIZONA Z LUKRECJA W EPIGRAMATACH ANDRZEJA KRZYCKIEGO*}

W artykule analizuję epigramaty Andrzeja Krzyckiego związane $z$ Lukrecją oraz $z$ osobą legata papieża Juliusza II, Jakuba Pizona ${ }^{1}$. Epigramaty te odwołuja się do iluzji malarstwa, które staje się nosicielem polemiki z Lukrecją, zrodzoną (na podstawie figuracji plastycznej) w umyśle Pizona. Występująca w nich aluzja literacka dotyczy przedstawienia malarskiego $\mathrm{z}$ jego moralno-pedagogicznymi, estetycznymi czy etycznymi celami. Musiała ona powodować pojawienie się całego zespołu odniesień do wrażliwości i wykształcenia czytelnika - od niego miało zależeć, które z nich rozpozna ${ }^{2}$.

Omawiane epigramaty, oznaczone w edycji Kazimierza Morawskiego numerami VI 4 (Piso in imaginem Lucretiae lascivius depictam, apud Cricium inventam) oraz VI 5 (Cricius pro Lucretia Pisoni), znajdują się w rękopiśmiennych przekazach Corpus Cricianum zazwyczaj obok siebie. Odwołam się także do kolejnego epigramatu, VI 6 (In Lucretiam lascivius depictam). Zbiór Carmina, stworzony przez Morawskiego wydaje się wątpliwy pod względem powiązań treściowych poszczególnych tekstów, niejednorodnych, jak i ich atrybucji. Każdorazowo wymaga wręcz konfrontacji z Corpus Cricianum ${ }^{3}$. W żadnym z epigramatów Lukrecja nie jest „lascivius depicta

* Krąg tekstów analizowanych w pracy stanowią trzy epigramaty z Carmina A. Krzyckiego w opracowaniu K. Morawskiego, oznaczone numerami VI 4, VI 5, VI 6 - zob. Andreae Cri i i i, Carmina. Ed. C. M or aw ski. Cracoviae 1888, s. 198-199 (tłumaczenia K. J eżew ski ej z wyd.: Antologia poezji polsko-łacińskiej 1470-1543. Oprac. A. J eli c z. Szczecin 1985, s. 184-185). O utworach związanych z motywem Lukrecji zob. W. W oj tow ic z, Szkice o poezji obscenicznej i satyrycznej Andrzeja Krzyckiego. Szczecin 2002, s. 153-169.

1 Zob. np. L. Domonkos, Jacobus Piso of Medgyes. Hasło w: Contemporaries of Erasmus: A Biographical Register of the Renaissance and Reformation. Ed. P. G. Bietenholz, Th. B. De uts ch er. T. 3: N-Z. Toronto 1995. Zob. też studia L. J a n kovit s a: Jacobus Piso, a Hungarian Humanist in Rome. W zb.: Italy and Hungary. Humanism and Art in the Early Renaissance. Ed. P. F a r b a ky, L. A. W ald m a n. Firenze 2011; „Vir tersissimus Iacobus Piso”. A Hungarian Humanist, Poet, and Diplomat in the Erasmian World. „Acta Conventus Neo-Latini Budapestinensis" 2010.

2 Zob. np. J. Axer, Tradycja klasyczna $w$ polskojęzycznej poezji renesansowej a mechanizmy odbioru tej poezji. „Pamiętnik Literacki” 1984, z. 2, s. 207-211.

3 Przyjęta przez Morawskiego kolejność epigramatów VI 4, VI 5 i VI 6 zgodna jest z ich kolejnościa w wykorzystanych przez niego rękopisach: Oss. 158 (tu s. 295-296), Jag. 2390, s. 361-362 (w Oss. 2304 brak zespołu Carmina amatoria). Podobnie dzieje się w nie wykorzystanych przezeń rękopisach Czart. 1448, s. 62/98; Racz. 61, k. 50r-50v; Sand. 1688, s. 108-109; Racz. 212, k. 254r-254v czy 
[zbyt swawolnie wyobrażona]" (jak głosza jednak dwa tytuły), co stanowi przyczynek do wad edycji tych tekstów, ale przede wszystkim wskazuje na „twórcze” redagowanie tytułów przez autora Corpus Cricianum - Stanisława Górskiego ${ }^{4}$. Wyłącznie pożądanie biseksualisty czy pederasty, Jakuba Pizona, przekształcające „specimen pudoris" w Florę, Taidę bądź Ganimedesa, konsekwentnie dopuszcza myśl o Lukrecji „zbyt swawolnie wyobrażonej”.

Analizowane epigramaty korzystają z retorycznych walorów evidentia ${ }^{5}$. Odbiorca dzięki sile ekspresji przedstawienia malarskiego może „zobaczyć głos” postaci ${ }^{6}$. Zarazem ekfrazy są literacką grą z obrazem Rzymianki. We wczesnej nowożytności stała się ona źródłem wielu wyobrażeń plastycznych ${ }^{7}$, wyzyskujących iluzję żywości i realności przedstawienia za sprawa jego „naoczności”. W wymiarze obyczajowym epigramaty sa satyrycznym ukazaniem preferencji seksualnych legata Jakuba Pizona. Odwołania do homoseksualizmu (sodomii) stanowią ujęcie topiczne - o czym przekonuje podrozdział 3 (Sodomia) z rozdziału 6 (Bogini natura) Literatury europej-

w manuskrypcie Bibl. Śląskiej 265, k. 60v (tu brak epigramatu VI 6, a tekst VI 5 urywa się na w. 5). W podstawowym manuskrypcie Corpus Cricianum, pochodzącym z Bibl. Kórnickiej, sygnowanym numerem 243, który gra rolę codex optimus (zob. też C. M or aw s ki, Praefatio. W: ed. cit., s. XIXIV), pomieszczono na składce 42 (k. 295r) polemikę z legatem Jakubem Pizonem (podaję odmienne warianty tytułów): Disticha Pisonis in imaginem Lucretiae Cricii (VI 4) i Cricius pro Lucretia Pisonis (VI 5) (teksty oznaczone jako poz. 404 i 405 w Katalogu rękopisów staropolskich Biblioteki Kórnickiej (Oprac. R. Marciniak, M. Muszyński, J. Wiesiołowski. T. 2. Wrocław 1985, s. 228)), podczas gdy epigramaty In imaginem Lucretiae: femina pudica (VI 2) i Responsio feminae urbanae (VI 3), jak również In eandem imaginem lascivius depictam (VI 6), znajdują się na na k. 349r składki 51 (poz. 543-545 w Katalogu rękopisów staropolskich Biblioteki Kórnickiej 〈s. 238〉). Składka 51 stanowi część drugiego, najwcześniejszego zespołu składek tego rękopisu, powstałych około połowy lat trzydziestych XVI wieku. Składka 42 - należąca do pierwszego zespołu składek - jest datowana, dzięki dokonanej przez J. Siniarską-Czaplicką analizie znaków wodnych (herb Odrowąż, poz. 728-730), na lata 1534-1541, ze wskazaniem na bliskość dolnej granicy (zob. Katalog rękopisów staropolskich Biblioteki Kórnickiej, s. 266). O rękopisach Corpus Cricianum, zob. Woj tow ic z, op. cit., s. 187-214.

4 Zob. W. Za k r ze w s k i, Stanisław Górski ijego prace historyczne. „Rozprawy Wydziału Historyczno-Filozoficznego Akademii Umiejętności” 1909. Ostatnio ukazało się studium P. Sapały The Górski Archive (Teki Górskiego) at the National Library of Poland: A Collection of Letters and Official Documents Pertaining to the Reign of King Sigismund I Jagiellon („Polish Libraries” 2019 〈tamże literatura〉).

5 Zob. B. Ni e b els ka-Raj c a, „Enargeia” $i$ „energeia” $w$ teoriach literackich renesansu $i$ baroku. Warszawa 2012, zwłaszcza s. 121-134.

$6 \quad$ Zob. ibidem, s. 122, z odwołaniem do: L. Mari n, O przedstawieniu. Przeł. P. Pi en iąż e k. Gdańsk 2011, s. 394-411.

7 O przedstawieniach wizualnych Lukrecji zob. np. K. H a n i ka: Lucretia als „Damenopfer” patriarchaler Tugendkonzeptionen. W zb.: Eros - Macht-Askese. Geschlechterspannungen als Dialogstruktur in Kunst und Literatur. Hrsg. H. S ci u ri e, H. J. B a ch or s ki. Vorwort H. J. B ac hor ski. Trier 1996; Eine offene Tür, ein offenes Mieder. Das Schicksal der Lucretia zwischen Vergewaltigung und Ehebruch. W zb.: Böse Frauen - Gute Frauen. Darstellungskonventionen in Texten und Bildern des Mittelalters und der Frühen Neuzeit. Hrsg. U. Gaebel, E. Kartschoke. Trier 2001. P. S c h n e id e r: "wann dies stückh aufgethan”. Bildakt in der Montierung - Der Selbstmord der Lucretia bei Lucas Cranach d. Ä. und Albrecht Dürer. W zb.: Et in imagine ego. Facetten von Bildakt und Verkörperung. Hrsg. U. Fe is t, M. Ra th. Berlin 2012; Der Selbstmord der Lucretia und die Ikonologie des Augenblicks. W zb.: Bild und Tod. Grundfragen der Bildanthropologie. Hrsg. P. St oellger, J. Wolff. T. 1. Tübingen 2016. 
skiej $i$ łacińskiego średniowiecza Ernsta Roberta Curtiusa ${ }^{8}$ - wartościowanym negatywnie, tu z wyraźną intencja satyryczną. Przykładowo, w literaturze wernakularnej średniowiecza, jak konstatował Wolf-Dieter Stempel, odniesienia do homoseksualizmu pojawiaja się w obrębie polemik, jako zarzut, czy we fragmentach o zamyśle satyrycznym ${ }^{9}$. Nienormalna aktywność seksualna była standardowym zarzutem w stosunku do osób oskarżanych o herezję, oskarżanie o praktykowanie sodomii zapewniało wygodny sposób pozbycia się kłopotliwych duchownych ${ }^{10}$. Satyryczny atak na legata dokonany za pomocą ekfraz może korzystać także $z$ wyobrażeń dotyczących (nie)moralnych zwyczajów kleru, jak przekonuje Guido Ruggiero, które są częste w antypapieskich wystapieniach, także w okresie sprzed reformacji ${ }^{11}$.

Postać Lukrecji, żony Tarkwiniusza Kollatynusa (Tarquinius Collatinus) ${ }^{12}$, pojawia się kilkakrotnie w zespole wierszy Krzyckiego (i temuż przypisywanych). Zgwałcona przez Tarkwiniusza Pysznego (Sextus Tarquinius), wybiera śmierć poprzez samobójstwo (pomimo uznania jej niewinności przez męża i ojca), co przyczynia się do usunięcia Tarkwiniusza i w efekcie wprowadza ostatecznie do Rzymu w 509 ro-

8 E. R. Curtius, Literatura europejska i łacińskie średniowiecze. Przeł. A. B or ow s ki. Kraków 1997, s. 122-125.

9 W.-D. S t e m p e1, Mittelalterliche Obszönität als literarästhetisches Problem. W zb.: Die nicht mehr schönen Künste. Grenzphänomene des Ästhetischen. Hrsg. H. R. J a u ß. München 1968, s. 194. Podobne: W. Beutin, Sexualität und Obszönität. Eine Literaturpsychologische Studie über epische Dichtungen des Mittelalters und der Renaissance. Würzburg 1990, s. 410 n. Zob. też V. L. Bullough, The Sin against Nature and Homosexuality. W zb.: Sexual Practices and the Medieval Church. Ed. V. L. Bullough, J. A. Brund a ge. Buffalo 1982, s. 55-71, 239-244. T. W a lt e r, Unkeuschheit und Werk der Liebe: Diskurse über Sexualität am Beginn der Neuzeit in Deutschland. Berlin - New York 1998, s. 273-279. U Krzyckiego tego rodzaju zarzuty pojawiają się w stosunku do osoby Jana Zambockiego (zob. W oj tow i c z, op. cit., s. 180-181). W odniesieniu do analizowanych wierszy zob. też T. N a s tulczy k, P. O c z k o: Homoseksualność staropolska. Przyczynek do badań. Kraków 2012; „iż ten zły zwyczaj do nas nie przyszedt”. Reprezentacje homoseksualności $w$ piśmiennictwie staropolskim. „Litteraria Copernicana” 2012, nr 1, s. 101-103.

10 Zob. G. Ruggi e r o, The Boundaries of Eros. Sex Crime and Sexuality in Renaissance Venice. New York 1985, s. 143.

11 Zob. ibidem, s. 141-144. O akceptacji i zasięgu postaw homoseksualnych w obrębie kleru w wiekach średnich zob. J. Boswe11, Christianity, Social Tolerance and Homosexuality. Chicago 1980, zwłaszcza s. 243-266 (rozdz. The Triumph of Ganymede: Gay Literature of the High Middle Age). Z prac podejmujących wątek Lukrecji zob. H. Galin s ky, Der Lucretia-Stoff in der Weltliteratur. München 1932. Motyw omawia także E. F r e n z el (Stoffe der Weltliteratur. Ein Lexikon dichtungsgeschichtlicher Längsschnitte. 10., überarbeitete und erweiterte Auflage. Stuttgart 2005, s. 548-553. Ogólne ujęcia: I. Donalds on, The Rapes of Lucretia. A Myth and its Transformations. Oxford 1982. - P. Holen s te in W e id m a n n, Passionierte Tugend: Lukrezia. „Deutsche Vierteljahresschrift für Literaturwissenschaft und Geistesgeschichte” 1994. - N. H olzb e r g, Metamorphosen des römischen Mythos in Antike, Mittelalter und Neuzeit am Beispiel der Lucretia-Legende. W zb.: Liviusinterpretationen. Hrsg. J. Gruber. Bamberg 1995. - J. Folla k, Lucretia zwischen positiver und negativer Anthropologie. Coluccio Salutatis „Declamatio Lucretie” und die Menschenbilder im exemplum der Lucretia von der Antike bis in die Neuzeit. Konstanz 2002 (na stronie: https://kops. uni-konstanz.de/bitstream/handle/123456789/12316/follak01-text.pdf?sequence=1\&isAllowed=y 〈data dostępu: 20 IV 2020〉). Antyczne spożytkowanie motywu Lukrecji omawia (w kontekście rzymskiej historiografii), przykładowo, B. Ko w a l e w s k i: Frauengestalten im Geschichtswerk des Titus Livius. München-Leipzig 2002. Zob. też T. G a c i a, Lukrecja- „dux romanae pudicitae” czy „mulier laudis avida”? „Roczniki Humanistyczne” 2009, z. 3. 
ku p.n.e ustrój republikański ${ }^{13}$. Lukrecja stanowi wzór rzymskiej cnoty; dokonując zamachu na własne życie, mówi: „I niech nie żyje w przyszłości żadna kobieta, która utraciła moralność, powołując się na przykład Lukrecji” (I 58) ${ }^{14}$. Jej postać jest niezwykle istotna dla konstruowania kobiecej tożsamości, miłości małżeńskiej, rozumienia cnoty bądź czystości w Europie przednowoczesnej. Samobójstwo Lukrecji odgrywało kluczową rolę w ujęciach prawnych, społecznych czy etycznych ${ }^{15}$. Stąd dla współczesnego czytelnika problematyczność odbioru epigramatów odwołujących się do przedstawienia wiążącego kompleksowo te treści ${ }^{16}$. Natomiast sam gwałt był naruszeniem czci męża, pod którego prawną opieką znajdowała się małżonka, szerzej zaś - rodu (czy rodziny). Utrata czci nie dotyczyła wyłącznie (ani nawet nie przede wszystkim) małżonki. Sprawą kluczową było znaczenie społeczne gwałtu, zakłócenie porządku społecznego, a nie przymus fizyczny w odniesieniu do jednostki ${ }^{17}$.

\section{Augustyn}

Czyn Lukrecji (obok tych dokonanych przez Marka Regulusa czy Katona) stanowił dla Augustyna dogodny pretekst do refleksji o samobójstwie ${ }^{18}$. Przewartościowuje on ów czyn w kontekście własnych rozważań w dziele De civitate Dei (I 19) na temat samobójstwa - to jego interpretacja będzie punktem odniesienia dla autorów średniowiecznych, trwale zmieni on perspektywę antycznych, w szczególności zawartą w ujęciu Liwiusza ${ }^{19}$. Augustyn wyraził, odmiennie niż uczynili to antyczni, niezgodę na samobójstwo, jego nieakceptowalność, uznając, iż brak jego rzeczywistego uzasadnienia w świetle moralności chrześcijańskiej ${ }^{20}$. Samobójstwo

Zob. Tytus Liwiusz, Dzieje od założenia miasta Rzymu. (Wybór). Przeł., oprac. W. Strzele cki. Wrocław 2004, s. 77-83. Zob. też Titi Livi Ab urbe condita. Recognovit et adnotatione critica instruxit R. M. O gilvi e. Oxford 1974, s. 76-82. Omówienie „mitu” w wymiarze społecznym, politycznym - zob. np. Do nald son, op. cit.

14 Tytus Liwiusz, op. cit., s. 80.

15 Zob. np. zbiór studiów pomieszczonych w Representing Rape in Medieval and Early Modern literature (Ed. E. Robert s o n, Ch. M. Ro s e. New York 2001). Zob. też D o nald s o n, op. cit.

16 Na tego rodzaju problematyczność treści wiązanych w przedstawieniach Lukrecji zwraca uwage H a nik a (Lucretia als „Damenopfer”. Patriarchaler Tugendkonzeptionen, s. 398).

17 S c h n e i d e r: „wann dies stückh aufgethan”. Bildakt in der Montierung - Der Selbstmord der Lucretia bei Lucas Cranach d. Ä. und Albrecht Dürer, s. 51-53 (tamże wskazania bibliograficzne); Der Selbstmord der Lucretia und die Ikonologie des Augenblicks, s. 183-184. Zob. też W a 1 t e r, op. cit., s. 218-221.

18 Augu stinu s, De civitate Dei, I 14 - I 28. W zb.: Patrologiae cursus completus. Series Latina. Accurante et denuo recognoscente J.-P. Mi g n e. T. 41. Parisiis 1845, kol. 28-42. Tematykę Lukrecji rozwija Augustyn w rozdz. 19 (ibidem, kol. 32-34). Zob. też G a cia, op. cit., s. 123-126. $\mathrm{O}$ dyskusji toczonej w obrębie patrystyki na temat cnót pogan (m.in. Lukrecja jako uosobienie fortitudo) zob. P. v on M o o s, Geschichte als Topik. Das rhetorische Exemplum von der Antike zur Neuzeit und die historiae im „Policraticus” Johanns von Salisbury. Hildesheim 1996, s. 321, przypis 631 (tamże literatura).

19 Zob. np. J. We itbre cht, Vergegenwärtigung der Antike. Lucretia in der Kaiserchronik und in den Römerdramen von Hans Sachs und Jacob Ayrer. W zb.: Antikes erzählen. Narrative Transformationen von Antike in Mittelalter und Früher Neuzeit. Hrsg. A. He in z e, A. Sch irrme ister, J. Weitbre cht. Berlin-Boston 2013, s. 75.

20 A u gu stin u s, op. cit., I 14 - I 28. Zob. też A. Alv a r e z, Bóg Bestia. Studium samobójstwa. Przeł. Ł. Som mer. Warszawa 1998, s. 66-69. 
Lukrecji, jak twierdzi Augustyn, skrywa w sobie przyznanie się do winy albo przedstawia sobą wręcz zabójstwo: „si extenuatur homicidium, adulterium confirmetur; si purgatur adulterium, homicidium cumuletur [jeśli usprawiedliwiać będziemy jej zabójstwo, potwierdzimy jej cudzołóstwo; jeśli ją znów z zarzutu cudzołóstwa oczyścimy, potęguje się wina jej zabójstwa]” (I 19) ${ }^{21}$. Zadany jej gwałt, dowodzi Augustyn nieco wcześniej, może być świadectwem (zakazanej) przyjemności, za którą Lukrecja odpokutowała własną śmiercią: „Quid si enim (quod ipsa tantummodo nosse poterat) quamvis iuveni violenter irruenti etiam sua libidine illecta consensit idque in se puniens ita doluit, ut morte putaret expiandum? [Bo (o czym sam tylko wiedzieć mogła) nuż, choć przemocą młodzieńca napastowana, miała jednakże upodobanie rozkoszne w grzechu i tak później tego żałowała, że postanowiła śmiercią okupić winę swoją?]"22. Jeśli zaś nie była ona cudzołożnicą argumentuje Augustyn - jej czyn nie wyraża umiłowania cnoty, to tylko niedoskonałość czy słabość samej tej cnoty: „non est pudicitiae caritas, sed pudoris infirmitas [nie jest to umiłowaniem niewinności, lecz słabością ze wstydu pochodząca]”. Lukrecja, podług Augustyna, jest „laudis avida nimium [nad wyraz dumna]”, a samobójstwo stanowi właśnie świadectwo „pudoris infirmitas [słabości pochodzącej ze wstydu]" ${ }^{23}$. W istocie karze się ona za cudza zbrodnię, czego nie czynią (i nie powinny czynić) chrześcijanki gwałcone przez barbarzyńców: „Non hoc fecerunt feminae Christianae, quae passae similia vivunt tamen nec in se ultae sunt crimen alienum [...] [Chrześcijańskie kobiety nie uczyniły tego: przecierpiawszy podobne znęcanie się nad nimi, żyją jednakże i siebie nie karały za cudzą zbrodnię $\langle\ldots\rangle\rangle$ ]"24. Mają one bowiem w sobie (,intus”) "gloria castitatis [pochwałę niewinności]”"25 (s. 45), której barbarzyńcy nie są w stanie naruszyć, a zatem obca jest im myśl o samobójstwie na wzór Lukrecji. Samobójstwo w takich okolicznościach nie nosi także znamion męczeństwa - Rzymiance brak było cnoty stałości, skoro zwróciła się przeciw własnemu życiu ${ }^{26}$.

Przyjętej przez Augustyna dwoistej perspektywy przewartościowującej ów czyn

21 Św. Augu st y n, Państwo Boże. Przeł. W. Ku bi cki. Kęty 2002, s. 44 . O wczesnochrześcijańskim rozumieniu samobójstwa zob. D. W. Am und s e n, Suicide and Early Christian Values. W zb.: Suicide and Euthanasia. Historical and Contemporary Themes. Hrsg. B. A. B ro dy. Dordrecht 1989. W odniesieniu do kultury wczesnonowożytnej zob. G. M i n o is, History of Suicide. Voluntary Death in Western Culture. Baltimore 2001, s. 72 n.

22 Św. Augu sty n, loc. cit. Zob. przykładowo uwagi A. Green sta d t w pracy „Rapt from himself”. Rape and the Poetics of Corporeality in Sidney's „Old Arcadia” (w zb.: Representing Rape in Medieval and Early Modern Literature. Ed. E. Robert s o n, Ch. M. Ro s e. New York 2001, s. 315-319). Zob. Augustinu s, op. cit., kol. 34. - Św. Augustyn, loc. cit.

Św. Augustyn, op. cit., s. 45.

Ibidem.

Jednak asocjacje tego rodzaju i stylizacje pojawiały się. Średniowieczne przykłady ujmowania samobójstwa Lukrecji jako wyrazu męczeństwa zbiera Galin s ky (op. cit., s. 20-39), tak przedstawiał je G. Ch a u c e r w The Legend of Good Women. Zob. też S. W e i g e l: Lucretia-Exemplum, Gründungsopfer und Blutzeugnis. W zb.: Märtyrer-Porträts. Von Opfertod, Blutzeugen und Heiligen Kriegern. Hrsg. S. W e ig e l. München 2007, s. 45-48; Exemplum and Sacrifice, Blood Testimony and Written Testimony: Lucretia and Perpetua as Transitional Figures in the Cultural History of Martyrdom. W zb.: Perpetua's Passions. Multidisciplinary Approaches to the Passio Perpetuae et Felicitatis. Ed. J. N. Bremmer, M. F or mis a n o. Oxford 2012. Krytycznie w stosunku do tez o ujmowaniu Lukrecji jako męczenniczki pisała Weitbre cht (op. cit., s. 245-246, przypis 9). 
Krzycki oczywiście nie akceptuje w wypadku wzoru rzymskiej cnoty - Lukrecji ${ }^{27}$. Ten archaiczno-heroiczny akt ujmowany jest w epigramatach bez powiązania go z wyobrażeniami Augustyna, z tradycjami tekstowymi pozostającymi pod jego wpływem. Krzycki, $z$ jednej strony, odwołuje się do rzymskiego rozumienia virtus, $\mathrm{z}$ drugiej - osadza wiersze w obrębie kultury dworu XVI stulecia, obracając je w satyryczne szyderstwo.

\section{Socration}

Obraz Lukrecji, którego właścicielem był Krzycki, zapewne obnażonej, przedstawionej przez nie znanego nam dziś malarza w momencie popełniania samobójstwa, bez wątpienia był swego rodzaju apelem do wrażliwości, wiedzy i moralności odbiorcy. Zgodnie $z$ duchem epoki malowidło przynosiło obraz stwarzający pozór życia, łudząco prawdziwy, a ten, kto ów obraz oglądał, stawał się „naocznym świadkiem" 28 . Temat (zachowanie i czyn Lukrecji, dowód rzymskiej virtus) oraz oczekiwania względem widza, jego kompetencji moralnych i wiedzy są znane. Tym samym ekfrazy Krzyckiego skrywaja potencjał performatywności, fingując dialog między odbiorca Pizonem a Lukrecja - postacią historyczną i wzorem cnoty.

W tekstowym medium Krzycki tworzy obecność Lukrecji (wrażenie obecności powstaje w malarstwie za sprawa enargei) oraz całe wydarzenie dowcipnego dialogu z Pizonem. Performatywność zostaje tu zawarta w tekście, symulując obecność postaci, wymianę spojrzeń, możliwość rozmowy ${ }^{29}$. Wymusza już w samym akcie patrzenia odpowiednie zachowanie. Posłuży ona ostatecznie do przekazu systemu wartości zogniskowanego na rzymskiej virtus. Jednak libido videndi nie przekształci się u Pizona w libido sciendi ${ }^{30}$.

Krzycki gra $z$ medialnością przedstawienia: każdemu ówczesnemu widzowi postać Lukrecji była znana, stąd pewne spektrum rozumienia, które ekfraza zakła-

27 Odmiennie dzieje się w innych utworach atrybuowanych Krzyckiemu. Oscylowanie między swego rodzaju wielowartościowością czynu Lukrecji (nadaną jej przez Augustyna) a próbami jego ujednoznacznienia widoczne jest w nie analizowanych tu epigramatach VI 2: In imaginem Lucretiae femina pudica, VI 3: Responsio feminae urbanae, oraz VI 8: In Lucretiam sese interficientem (Andreae Cricii Carmina, s. 197-198, 201). Mają one wymowę mniej lub bardziej obsceniczną. Gorszyła ona C. B a ckvis a (Eaciński poeta Polski humanistycznej Andrzej Krzycki-Andreas Cricius 〈1482-1537〉. W: Szkice o kulturze staropolskiej. Przeł., oprac. A. B i e r n a c ki. Warszawa 1975, s. 62): „Trzeba było mieć bardzo dziwaczny smak, aby w duchu szyderczego cynizmu zabawiać się przedstawianiem tego, co kobieta rzekomo "normalna" [femina urbana - W. W.] zrobiłaby na miejscu Lukrecji, której sztywnej i ostentacyjnej cnoty Krzycki nie mógł ścierpieć. Jednak jeszcze dziwniejszego gustu trzeba było, by ułożyć nowy utwór, który dowodzi, że w gruncie rzeczy Lukrecja, zanim przybrała swoją wymuszoną pozę, zażywała rozkoszy uścisku Tarkwinusza, i by napisać na ten temat serię dwuznaczników, od których włosy stają dęba”. Zob. też W o j to wi c z, op. cit., s. $158 \mathrm{n}$.

28 Niebelska-Rajca, op. cit., s. $128 \mathrm{n}$.

29 Zob. I. M a a s s e n, Text und / als/ in der Performanz in der frühen Neuzeit. Thesen und Überlegungen (mit einem Appendix von M. Pfister: Skalierung von Performativität). „Paragrana. Internationale Zeitschrift für Historische Anthropologie" 2001, z. 1, s. 291.

30 Zob. H. Schlie, Schöpfung, Erkenntnis und Tabu im Medium. Der Blick auf den weiblichen Akt bei Pierre Ronsard und François Clouet. W zb.: Neugier und Tabu. Regeln und Mythen des Wissens. Hrsg. M. B ais ch, E. Ko ch. Freiburg 2010, s. 279-285. 
da, które staje się wszakże podmiotowym złudzeniem Pizona. Tak ukazana jest Lukrecja, rzymski wzór cnót:

\author{
Mascula suspicior laeto Lucretia vultu; \\ Tunc mea cum foderem pectora talis eram. \\ [Męską Lukrecję widzisz tu z pogodną twarzą \\ Taką byłam, gdy nożem godziłam w swą pierś.] [VI 4, w. 1-2]
}

Kulturowa wiedza o Lukrecji wzmacniała u odbiorcy już w samym akcie percepcji dzieła ocenę moralną sytuacji granicznej, w której znajdowała się bohaterka wiersza. W akcie widzenia przedstawienie malarskie musiało zostać zrozumiane w swych szczegółach, poddane ocenie już na tym etapie ${ }^{31}$. Renesansowe rozumienie obrazu jest tu szczególnym przykładem performatywności sztuki wizualnej. Obraz ujęty za pomoca ekfrazy staje się medium, które pozwala uchwycić jego performatywność w relacji z odbiorca poprzez apel do zasobów wiedzy (i moralności) tegoż. Performatywność ujawnia się w spojrzeniu, zawiera się w nim, kluczowa jest tu rola widza - Jakuba Pizona - z jego podważeniem autorytetu rzymskiej tradycji (także wartości religijnej obrazu), alegorii virtus. Czyn Lukrecji jest zdany na opinię spoglądającego, konstytuuje się w nim. Ten dwugłos, dwuspojrzenie czy sprzeczność (za sprawą niewłaściwej interpretacji Pizona, nie umiejącego odtworzyć w swej duszy emocji związanych z sytuacją Lukrecji, do czego przyczynia się projektowanie jej nowej, niespotykanej roli społecznej) staje się przedmiotem dworskiej gry dowcipu.

Obecność Lukrecji, jej odpowiedzi i reakcja są symulowane - w przeciwieństwie do reakcji i słów Pizona, przynajmniej tak, jak je nam ukazuje Krzycki.

Prezentacja wydarzeń stanowi także apel do kompetencji poznawczych: wiedzy oraz moralności odbiorcy. Jest on niejako zeń odpytywany - jego udział w przesłaniu obrazu zostaje w pewnym sensie $z$ tymże obrazem zintegrowany ${ }^{32}$, co podkreśla gra Lukrecji ze spojrzeniem i myślami nowego Tarkwiniusza - legata Jakuba Pizona. Dylemat moralny przedstawienia polega na powierzeniu odbiorcy odpowiedzialności za dziejąca się „historia”, która staje się w jego akcie rozumienia i wartościowania ukazanego wydarzenia - stąd Pizo może być Tarkwiniuszem, gdyż "historia” nie dokonała sie jeszcze ${ }^{33}$.

Za sprawa wzroku Pizona (a jest to próba poznawania przez człowieka post lapsum, wyraża zatem jego grzeszność, w konsekwencji niedostrzeganie boskich praw $^{34}$ ) przekształci się Lukrecja w Taidę, wreszcie w Ganimedesa:

Zob. S c h n e i d e r, „wann dies stückh aufgethan”. Bildakt in der Montierung - Der Selbstmord der Lucretia bei Lucas Cranach d. Ä. und Albrecht Dürer, s. 51.

32 Zob. S c hn e i d e r, Der Selbstmord der Lucretia und die Ikonologie des Augenblicks, s. 196-198.

33 Scena samobójstwa Lukrecji stawała się także apelem do zgromadzonych przy niej mężczyzn (obok ojca i męża był tam Lucius Iunius Brutus oraz Publius Valerius), wezwaniem do czynu: po usunięciu Tarkwiniusza Collatynus i Lucius Iunius Brutus zostaja pierwszymi konsulami tak buduje swa prezentacje wizualną H. Goltzius (zob. Hanika, Lucretia als „Damenopfer” patriarchaler Tugendkonzeptionen, s. 405). Jeśli podobna intencja była zawarta w przedstawieniu, którym dysponował Krzycki, widać tym bardziej nader „opaczna” i niekompetentną reakcję Pizona.

34 Zob. przykładowo Schlie, op. cit., s. 276-279. 
E Flora ut fierem Lucretia fecit Apelles ${ }^{35}$; Naturam quis plus arte valere putet? ${ }^{36}$

Ista mori non est, subigi sed imago volentis, Hos gladio digitos exue, Thais erit.

Contegat ista suas Lucretia veste papillas Atque aquilam teneat, Phryx Ganymedes erit.

[Apelles sztuką Florę przemienił w Lukrecję Któż przyzna sztuce mniejszą niż naturze moc?

- Nie umrzeć chcącej obraz to, lecz chcącej ulec, Tais to będzie, jeśli z rąk wyjmiesz jej miecz.

Niech ta Lukrecja suknia zakryje swe piersi I orła trzyma - będzie z niej Ganimed, Fryg.] [VI 4, w. 3-8]

Gra znaczeń to gra zmysłów i myśli. Lukrecja przez moment okazuje się figurą niestała. Refleksja skupiona na obrazie, jego idące w detale rozważenie, staje się jak najbardziej realne, tyle że wizualizacja treści obrazu jest całkowicie błędna, przekracza możliwość właściwej oceny przez oglądającego, zwrotnie: stanowi świadectwo jego moralności. Krzycki podejmuje motyw na sposób manierystyczny. Sztuka z Flory uczyni Lukrecję, z niej Taidę i wreszcie Ganimedesa ${ }^{37}$ - dzieje się tak jednak za sprawa seksualnego pożądania Pizona. Powstaje ewokowany przez obraz związek między jego spojrzeniem a obiektem przedstawienia - Lukrecją.

Seksualna „dyspozycyjność” kobiety w oczach Pizona koresponduje tu z wyższością mężczyzny, narzucającego (co dalej będzie jeszcze podjęte $z$ intencją ironiczna) kobiecie pasywność. Relacje między władzą a małżeństwem, kluczowe dla narracji o Lukrecji (stale wykorzystywane w transformacjach motywu) zostaja w sposób zabawny przekształcone dzięki intencji satyrycznej. Przypominając akcentowana przez Kennetha Clarka różnicę między „nude” a „naked” (w polskim tłumaczeniu: aktem a nagością) ${ }^{38}$ - w świetle tych rozważań akt nie ma niczego wspólnego $z$ nagością („kreaturalnością) stworzenia - zwrócić uwagę należy na idealizowanie, metaforyzowanie i, ostatecznie, odseksualizowanie aktu kobiecego

O dażeniu do realności w sztukach przedstawiających zob. Ni eb els k a - Raj c a, op. cit., s. 126. Apelles (obecny u Krzyckiego także w Epitalamion Sigismundi regis et Barbarae reginae Poloniae 〈w. 92〉) - obok Zeuksisa czy Parrazjosa - funkcjonuje w świadomości kulturowej epoki jako najdoskonalszy w tworzeniu złudzenia realności. Wiedzę o nim zawdzięczają artyści renesansu źródłom klasycznym, głównie Plin i u s z ow i (Historia naturalis, ks. XXXV, rozdz. 65). Nacisk na konceptualizowanie problematyki, kreowanie rzeczywistości artystycznej łudząco podobnej do realiów był niezwykle silny wśród twórców i teoretyków renesansu (ibidem, s. 127).

O rozumieniu relacji między naturą a sztuką (w opisach pięknej kobiety i/czy mężczyzny) zob. przykładowo Curtiu s, op. cit., s. 189-190. Zob. też M. M ej or, Książę Mikołaj Radziwiłt przy grobie Cycerona. W zb.: Studia neolatina. Rozprawy i szkice dedykowane profesor Marii Cytowskiej. Red. B. Milewska-Waźbińska, M. M ejor. Warszawa 2003, s. 121. W odniesieniu do traktatów dotyczących malarstwa i poetyk renesansu zob. np. A. E u s t e r s c hul t e, Imitatio naturae. Naturverständnis und Nachahmungslehre in Malereitraktaten der frühen Neuzeit. W zb.: Kunste und Natur in den Diskursen der frühen Neuzeit. Hrsg. B. Becker-Cantarin o, H. La u fh ütte. T. 2. Wiesbaden 2000. - A. Sch mitt, Mimesis bei Aristoteles und in den Poetikommentaren der Renaissance. W zb.: Mimesis und Simulation. Hrsg. A. Kablitz, G. Neumann. Freiburg im Breisgau 1998.

K. Cla rk, Akt. Studium idealnej formy. Przeł. J. B o m b a. Warszawa 1998, s. 9-29. 
w perspektywie sztuki humanizmu ${ }^{39}$. Krzycki gra niejako na tej dwojakiej perspektywie: rzekomej seksualności aktu Lukrecji i jej rzeczywistym, symbolicznym odseksualizowaniem.

Scena, w której Lukrecja znajduje się zawieszona między życiem a śmiercią, ulega dzięki teatrowi pożądliwej wyobraźni Pizona rozwinięciu w zaskakujące inscenizacje cielesności i seksualności: Lukrecja, przemieniona z Flory, staje się Taidą, wreszcie może stać się Ganimedesem. Pożądanie obdarza intelekt Pizona świadomością identyczności niepodobnych rzeczy - uprzednio nie znanej. Racja niezwykłości tkwi w podmiotowym widzeniu rzeczywistości, odmieniającym to, co jedynie naturalne. Dzieje się wszakże tak za sprawą pożądania: moc jego jest tak wielka, że Pizo w miejsce Lukrecji wyobraża sobie Taidę, co więcej - skłonny jest wierzyć $\mathrm{w}$ swe wizje podsuwane mu przez pożądanie. Jednocześnie inscenizacja „sceny miłosnej”, która ma poruszyć emocje odbiorcy, ujawnia u Pizona deficyty dworskich manier ${ }^{40}$, zwłaszcza tych dotyczacych obcowania $\mathrm{z}$ kobieta.

Lukrecja przywraca właściwą miarę swej osobie:

Non Flora aut Thais, sed sum Lucretia, Piso, Verum sic spectans tu mihi Tarquinius.

Nec subigi, sed imago mori sum Piso volentis, At tu quod velles me quoque velle putas.

Guod tibi sum tectis Ganymedes Piso papillis, Nimirum mihi tu Iuppiter esse velis.

[Lukrecjam ja, Pizonie, nie Flora ni Tais; Widząc ją we mnie, sameś Tarkwiniuszem mi.

I nie ulec, lecz umrzeć chcącej jam obrazem, A ty tego, co sam chcesz, widzisz we mnie chęć.

Że Ganimedem bym się zdała pierś zakrywszy,

To pewnie ty Jowiszem chciałbyś dla mnie być...?] [VI 5, w. 1-6]

Moc pożądania dostarcza fałszywych wizji, przekonań czy niewłaściwej wiary. Pożądliwość Pizona w aktualizującej myśli Lukrecji (pogłos chrześcijańskiej anamnezy?) zmienia go w Tarkwiniusza $z$ całą brutalnością i perfidią jego czynu. Staje się on przyczyną samobójstwa Lukrecji. (I jest to błędne przekształcenie czy modyfikacja ikonicznego skryptu obrazu przedstawiającego samobójstwo Lukrecji w akcie recepcji, rozwijana przez Pizona.)

Ujęcie czynu Lukrecji na obrazie, którego dysponentem był Krzycki, Lukrecji ukazanej zapewne w momencie popełniania samobójstwa, jego recepcja, ma dwa aspekty: bezpośrednia recepcja (w oparciu o przeżywany erotyzm Pizona), która znosi, unieważnia inny aspekt doświadczania przedstawienia: zawartej tamże „historia" odwołania do wiedzy obserwatora żyjącego w roku 1510, także do jego poczucia moralności. Percepcja Pizona jest tym samym swego rodzaju aktem barbarzyństwa w stosunku do Lukrecji, ,aktualizacja” czynu Tarkwiniusza - pomimo pozornie błyskotliwych, erudycyjnych odwołań do Flory czy Ganimedesa. dworach zob. przykładowo R. G. As c h, Hof, Adel und Monarchie. Norbert Elias' Höfische Gesellschaft. W zb.: Höfische Gesellschaft und Zivilisationsprozess. Hrsg. C. O p it z. Köln 2005. 
Lukrecja broni swej tożsamości: „sed sum Lucretia Piso”. Wątpliwości co do intencji Lukrecji, sensu jej czynu, wymowy postaci, gestu i ciała zostają rozwiane. Jej nagość jest nagością heroiczną.

W kolejnym dystychu autor w przemyślany sposób obniża tonację utworu. Lukrecja umiejętnie podejmuje gre $z$ Pizonem i $z$ jego fantazjami erotycznymi, $\mathrm{w}$ istocie: $\mathrm{z}$ męską dominacja i $\mathrm{z}$ przemocą seksualną. Parodystycznie nawiązuje do jego erotycznego pożądania, płeć jest także i tu funkcją roli społecznej ${ }^{41}$. Rozpoczęty przez Pizona proces konstruowania „nowej” erotycznej tożsamości Lukrecji zostaje przejęty, przebiega teraz pod znakiem szyderczej fantazji erotycznej Rzymianki, ,autentyczna” Lukrecja ukazuje „autentycznego” Pizona:

Quod tibi sum tectis Ganymedes Piso papillis,

Nimirum mihi tu Juppiter esse velis.

Mascula si videor, non dicito me Ganymedem,

Sed mihi sis Piso, sim tibi Socration ${ }^{42}$.

[Że Ganimedem bym się zdała pierś zakrywszy,

To pewnie ty Jowiszem chciałbyś dla mnie być...?

A jeśli męska zdam się, nie zwij Ganimedem,

Pizonem bądź mi, bedęć Sokrationem ja.] [VI 5, w. 5-8]

W fikcyjnej rozmowie przegląda się ważna cecha kultury wczesnej nowożytności, jej „teatralność”, w której status społeczny i tożsamość zależały w wysokim

41 W pewnym sensie wiersze te sa pendant do tez J. B utler (Excitable Speech. A Politics of Performative. London 1997) o performatywnym wymiarze czy tworzeniu tożsamości płci (płciowej), o płci jako funkcji roli społecznej.

„Socration” w epigramacie VI 5 jest w ocenie piszącego te słowa „Sokratesem” bądź zdrobnieniem tej nazwy własnej, „pochodzacym” - według Morawskiego (ed. cit., s. 199, przypis 1) - z Katullusa 47 (zob. Katullu s, Poezje wszystkie. Przeł. G. Franczak, A. Klęczar. Wstęp A. Kl ę c z a r. Tyniec 2013, s. 328-329). Zob. też D. Si d e r, The Epigrams of Philodemos: Introduction, Text, and Commentary. Oxford 1997, s. 23-24 (forma „Socration” to zdrobnienie od „Sokratesa”). - S. O. Shapiro, Socration or Philodemus? Catullus 47 and prosographical Excess. „The Classical Journal” 2014, nr 4, s. 394-395 (tu sceptycznie, z konkluzją: „But while such a diminutive is certainly possible, it is not actually attested in either Greek or Latin [Chociaż takie zdrobnienie jest $\mathrm{z}$ pewnością możliwe, nie jest ono faktycznie poświadczone ani w języku greckim, ani w łacińskim]”, s. 395). Przydomkiem „Sokration” miał cieszyć się Filodemos z Gadary w epikurejskich kręgach Neapolis, to do tego przydomka odwoływałby się Katullus (zob. też F. Cairn s, Roman Lyric: Collected Papers on Catullus and Horace. Berlin-Boston 2012, s. 115-212). Moim zdaniem, aluzja ta, choć możliwa, nie buduje żadnych rozpoznawalnych sensów w wierszu Krzyckiego, dlatego też - jak sądzę - „Socration” odnosi się do Sokratesa (za sprawą znajomości Katullusa 47), choć nie rozstrzygniemy także i dziś, czy jest to dla Krzyckiego forma zdrobnienia, czy nie (zob. Si d e r, op. cit. - S h a p i r o, op. cit.). Najwyraźniej też świadomości kulturowej Krzyckiego obcy był pomysł egzegetyczny G. Friedricha z jego edycji Catulli Veronensis Liber (LeipzigBerlin 1908, s. 228), łączący „Socrationa” z Filodemosem z Gadary (i ciągnąca się już stulecie dyskusja wokół „adresatów” inwektywy Katullusa, podważonej w tekście Shapiro 〈op. cit., s. 386>, gdzie Porcius i Socration to jedynie „nazwiska znaczące”. Krzycki widzi w tym wypadku „Sokratesa” lub „Sokratesika” i czyni aluzję w oparciu o jego związek z Alkibiadesem, tu zaś - z Pizonem (któremu przypisuje się pasywną rolę w związku homoseksualnym na wzór roli tegoż Alkibiadesa). Kulturowe aluzje te zapewne czytelne były dla kręgu adresatów satyry Krzyckiego (o recepcji poezji Katullusa w renesansie zob. J. Ha ig G a is s e r, Catullus in the Renaissance. W zb.: A Companion to Catullus. Ed. M. B. Skinner. Oxford 2007). Zob. też N a stulczy k, Oczko, „iż ten zły zwyczaj do nas nie przyszedł”, s. 102-103. 
stopniu od umiejętnie prowadzonej prezentacji wobec publiczności, ale także wobec norm społecznych ${ }^{43}$. Skoro Jakub Pizo nie uznał wzoru cnót w osobie Lukrecji, Lukrecja ukaże wzory do niego przystające. Kobieca pasywność zostaje przeciwstawiona męskiej dominacji: Lukrecja podejmuje rolę aktywnego homoseksualisty, narzucając pasywność, kobiecość Pizonowi. Jak zauważa Monika Miazek-Męczyńska, omawiając średniowieczne i wczesnonowożytne wzorce osobowe kobiety w kontekście chrystianizmu: kobieta mogła przekształcić się w silnego męża i przestać być (wbrew swym duchowym oraz cielesnym deficytom) nieudanym i chromym rodzajem mężczyzny - w dwa różne sposoby: „pozostać kobietą, ale zachowywać się jak mężczyźni lub stać się dla świata mężczyzną, by postępować jak mężczyźni”"44. Męska Lukrecja zmienia się zatem w męża dla legata i postępuje $z$ nim jak mąż z kobietą. Lukrecja Krzyckiego przekształca strukturę w sposób kreatywny. (Satyryczne ujęcie preferencji seksualnych legata ma oczywiście bliski związek z zasadniczą nieufnością w stosunku do płci żeńskiej - jej rewersem jest docenianie męskiej virtus w Lukrecji.)

Krzycki korzysta tu z aluzji dotyczącej relacji seksualnych Sokratesa w stosunku do Alkibiadesa - postać tę szereg średniowiecznych komentatorów „przekształcało" w kobiete ${ }^{45}$.

Krzycki przemawiający w imieniu Lukrecji, być może, asocjuje własną tożsamość z małżonkiem tejże Lukrecji - agresywne i obsceniczne aluzje są swego rodzaju odpowiedzią na naruszona przestrzeń dworską domu przez legata: wręcz zemstą.

Przy pomocy Lukrecji udziela autor legatowi lekcji moralności (co odróżnia satyryczne wiersze od innych związanych $z$ Lukrecja a umieszczonych przez Morawskiego, za Górskim, niefortunnie w zespole Carmina amatoria). Lekcję moralności puentuje kolejny (w edycji Morawskiego) epigramat:

\author{
Si videor lasciva tibi spectator imago, \\ Dic maius specimen quale pudoris habes? \\ Virtutem factumque meum mireris in ista \\ Forma, sic fiam religiosa tibi.
}

Zob. klasyczne studium R. Ale w y n a Das große Welttheater (Hamburg 1959) czy W. B a r n e r a Barockrhetorik. Untersuchungen zu ihren geschichtlichen Grundlagen (Tübingen 1970). Zob. też M a a s s e n, op. cit., s. 293-294, 297-300.

M. Miazek-M ę c zyńska, Przeistoczenie $w$ mężczyznę jako kobieca szansa na zbawienie? Święta z broda, jezuitka, papieżyca. W zb.: Płeć i wtadza $w$ kontekstach historycznych $i$ wspótczesnych. Red. M. A. Kubia czyk, F. Kubia czy k. Gniezno 2014, s. 102. Autorka wskazuje m.in. na trzy święte, które, chroniąc się przed męską pożądliwością, same stały się mężczyznami, jak (w jakiejś mierze) przydarzyło się to św. Galli, św. Wilgefortis i, całkowicie, św. Pelagii oraz św. Margericie/Pelagiuszowi (ibidem, s. 105-109).

45 Zob. np. W a lt e r, op. cit., s. 277. Z kolei o relacjach między Sokratesem a Alkibiadesem (,jako się Sokrates przeciwko Alcybiadowi zachowywał") (nie)wspomni w kategoriach relacji homoseksualnych choćby $Ł$. Górnicki w swym tłumaczeniu Il Cortegiano B. Castiglionego: Dworzanin polski. Oprac. R. Pollak. T. 1. Wrocław 2004, s. 15. BN I 109. Zob. też G. D all' O r to, „Socratic Love” as a Disguise for Same-Sex Love in the Italian Renaissance. „Journal of Homosexuality” 1989, $\mathrm{nr} 1 / 2$, s. 46, 60. - W. Ols z a n i e c, „Maxime omnium legitime Socrates amavit”. Marsilio Ficino $i$ odniesienia do homoseksualizmu $w$ dialogach Platona. W zb.: Glosy filologiczno-filozoficzne na marginesie prac Profesora Juliusza Domańskiego w osiemdziesiata piata rocznicejego urodzin. Red. J. Kw a p i s z, W. O1s z a n i e c. Warszawa 2012, zwłaszcza s. 209-210. 
[Jeśli, widzu, mój obraz zda ci się swawolny,

To jakiż wstydliwości obraz lepszy masz?

Ty czyn mój i mą cnotę w tym kształcie podziwiaj,

A wtedy stanę ci się tu czcigodnym kimś.] [VI 6, w. 1-4]

Jeśli „specimen” jest (po prostu) synonimem średniowiecznego „exemplum”, to Krzycki przedstawia w kolejnej ekfrazie w istocie „historia” rzymskiej Lukrecji, zawężając możliwe strategie odbioru tej wizualizacji. „Historia” nie stanowi wyłącznie (ani nawet nie przede wszystkim) przekazu informacji. Perspektywa ta jest obca czy to średniowieczu, czy wczesnej nowożytności ${ }^{46}$. „Historia” jest exemplum, przykładem ${ }^{47}$, który wykracza daleko poza wizualną prezentację (całkowicie zniekształconą wskutek pożądliwości legata, jak widzieliśmy to w poprzednich epigramatach), stanowi wzorzec wstydu (pudor) właśnie, a za jego sprawą - cnoty (virtus): jest czymś świętym czy pobożnym (stąd imago jest religiosa ${ }^{48}$ ). Tym samym wykracza poza jednostkowe zdarzenie w rzymskiej przeszłości - wykracza poza spojrzenie oglądającego, przekazuje sobą nauki moralne, staje się reprezentacją pewnych modelowych etycznych zachowań w obrębie ponadjednostkowych sytuacji, a dzięki temu z kolei skłania odbiorcę do poprawnych etycznie zachowań. Już na samym początku pociaga to za sobą właściwą ocenę przedstawienia Rzymianki: „Virtutem factumque meum mireris in ista / Forma, sic fiam religiosa tibi" - jak głosi Krzycki.

Ostatni z przywołanych epigramatów ukazuje, w jaki sposób obraz jego ekfraza) może ustanowić pewne nieneutralne oczekiwania względem swojego odbioru (a jednocześnie „zażądać” od odbiorcy uchwycenia kontekstu i możliwych odniesień etycznych prezentowanej „historia”). Epigramat ten niejako puentuje całkowicie błędny odbiór Lukrecji przez Pizona: nie rozpoznaje on ani oczekiwań, ani też nakazów wobec siebie. Jego rola jako legata papieskiego predestynowała go do przyznania wysokiej rangi tak czci, jak cnotom, duże znaczenie powinna też mieć kontrola afektów (ujmując rzecz przez pryzmat rozważań Norberta Eliasa ${ }^{49}$ ). Wszystko to ogniskuje się w refleksji nad podstawowymi kwestiami moralnymi poprzez uznanie przez odbiorcę niewinności Lukrecji za sprawa jej heroicznej nagości. Tym samym Pizo rujnuje swój „kapitał społeczny”, niewłaściwie odczytując znaczenie i moralne (ale także religijne) przesłanie obrazu Krzyckiego. (Końcowa aluzja do Ganimedesa, ujawniająca homoseksualizm Pizona, to również podkreślenie jego oddalenia od Boga, defektów jego religijności.) Swego rodzaju cytat z Lukrecji w epigramacie VI 5 (Cricius pro Lucretia Pisoni) w istocie niszczy uosabiana przez nią normę kulturową. Narusza i fikcjonalność przedstawienia, i jego wymiar estetyczny - jak uczynił to Pizo. Szerzej: to, co zasługuje na pochwałę, przekształ-

46

Zob. np. J. Kn a pe, Historie in Mittelalter und früher Neuzeit, begriffs- und gattungsgeschichtliche Untersuchungen im interdisziplinären Kontext. Baden-Baden 1984. - Moos, op. cit., s. 148 (tu obszerny przypis $353 \mathrm{z}$ literatura).

Chodzi o przykłady mieszczące się w kategoriach exempla imparia - zob. H. La u s b e r g, Retoryka literacka. Podstawy wiedzy o literaturze. Przeł., oprac. A. Gorzkows ki. Bydgoszcz 2002, s. 255 n. (§ 419 n.).

Nie wyklucza to kolejnej gry ironii - „religiosa” w łacinie średniowiecznej to także „zakonnica”.

N. Elias, O procesie cywilizacji. Analizy socjo- i psychogenetyczne. Przeł. T. Zabłud ows ki, K. Marki ewi cz. Warszawa 2011. Zob. też m.in. W. W oj t ow i c z, Między literatura a kulturą. Studia o „literaturze mieszczańskiej” przełomu XVI i XVII wieku. Szczecin 2010, s. 157-176. 
ca się w to, co wymaga nagany - za sprawą medialności przekazu, pozostawiającego nas sam na sam ze złudzeniami Pizona.

Pewnego rodzaju otwartość obrazu zaprasza do rozstrzygnięć na temat jego zawartości, ale także wyraża oczekiwania co do możliwych jego ujęć: obraz nie tylko mediatyzuje niejako i tematyzuje wiedzę obserwatora, ujawnia również jego konstytucję moralną - staje się ona jak gdyby częścią przedstawienia ${ }^{50}$. Tożsamość Lukrecji wymaga jej ukonstytuowania w akcie rozumiejącego spojrzenia, co powinno nadawać spoglądającemu, jak i przedstawieniu oczywistą koherencję moralną oraz intelektualną.

\author{
Abstract \\ WITOLD WOJTOWICZ Institute of Literary Research of the Polish Academy of Sciences, \\ Warsaw \\ ORCID: 0000-0002-8278-7948

\section{SPECIMEN PUDORIS, OR ON THE CONVERSATION BETWEEN JACOBUS PISO AND LUCRETIA IN ANDREAS CRICIUS' EPIGRAMS} \\ In the paper the author analyses the New Latin epigrams by Andreas Cricius (1482-1537) connected \\ with Lucretia and with the figure of Jacobus Piso (? -1527), a legate of the Pope Julius II, produced \\ probably in the year 1510. The epigrams refer to the illusion of painting, concern the painterly illustra- \\ tion of Lucretia's suicide to which they assign moral-pedagogical, aesthetic, and ethic aims. Rich liter- \\ ary allusions of satirical character in Cricius' epigrams are directed against Piso-they are satirical \\ depiction of the legate's homosexual preferences.
} Frühen Neuzeit. Hrsg. Ch. Krus e, P. Schneider, H. Bredeka m p. München 2010. 